\title{
Where Might the Hands-off Protection Strategy of Anastomosing Rivers Lead? A Case Study of Narew National Park
}

\author{
Paweł Marcinkowski*, Marek Giełczewski, Tomasz Okruszko \\ Department of Hydraulic Engineering, Faculty of Civil and Environmental Engineering, \\ Warsaw University of Life Sciences, Warszawa, Poland
}

Received: 2 August 2017

Accepted: 16 October 2017

\begin{abstract}
Anastomosing rivers were historically common around the world before agricultural and industrial development in river valleys. Presently, one preserved example of this type of river in Europe is the Upper Narew River in Poland. The uniqueness of the river determined embracing the $35 \mathrm{~km}$-long section of its length and adjacent valley by formal protection as Narew National Park (NNP) and a Natura 2000 site. At present, the NNP Authorities are implementing a hands-off strategy focusing on maintenance of the processes. To assess the efficiency of such a policy, the current hydromorphological conditions of anastomosing river reach in NNP and the historical changes of the river planform at reach scale were recognized. The hierarchical framework tool (HF) was used for this purpose. Although current processes seem to prefer anastomoses maintenance, an analysis of historical river changes showed an accelerating pace of channel extinction. The anastomosing planform of the Narew was created through natural processes, but it has been maintained through a long history of human use and modification of the river system. The hands-off approach to direct channel management will most likely result in the further loss of anabranches, and hence the hands-on protection strategy seems to be a reasonable solution for protecting the NNP.
\end{abstract}

Keywords: anastomosing river, hydromorphological assessment, hierarchical framework, Narew National Park, hands-off protection

\section{Introduction}

Anastomosing rivers constitute a rare example of multi-channel fluvial systems that for a long time were frequently confused with braided rivers. Schumm [1] may have been the first to point out that the term

*e-mail: p.marcinkowski@levis.sggw.pl "anastomosing" should not be used as a synonym for braiding, and hence, at present, it is reserved for a type of river with multiple, interconnected, permanent, coexisting channel belts on alluvial plains [2]. These multichannel systems, characterized by low stream slopes and low specific stream energy [3], occur in a variety of environments and climatic conditions varying from subarctic or temperate to tropical humid or arid [2, 4-6]. Since the vast majority of anastomosing rivers are morphologically quite similar, they can be considered 
as an example of an equifinal system, i.e., different combinations of processes or causes produce a similar form [7]. Their origin and development is controlled by the avulsion process, which is the diversion of flow from an existing channel onto the floodplain, eventually resulting in a new channel belt [8-12]. Anastomosing rivers would have been historically common in low-gradient, alluvial valleys worldwide prior to the expansion of agriculture and urbanization, triggering extensive modifications of rivers and their floodplains [13]. However, a small number of studies reported worldwide until nowadays and studies evidencing their extinction [13-14] might lead to the conclusion that only several anastomosing systems remain worldwide and a special focus on their investigation is highly required.

Currently one of the best-preserved examples of cohesive sediment, an anastomosing type of river in Europe is the Upper Narew River in northeastern Poland [12]. The uniqueness of the river resulted in a $35 \mathrm{~km}$-long section and adjacent valley falling under formal protection as Narew National Park (NNP) in 1996, and establishment as a Natura 2000 site (Bird and Habitat Directive). The main protection subject stated in the protection plan [15] is the multi-channel nature of the river, which constitutes a geomorphological phenomenon on an international scale. However, the cumulative effect of human activities beginning from the $19^{\text {th }}$ century led to a substantial deterioration of the anastomosing system state [16]. The gradual extinction of anastomoses is a major problem that is faced by NNP authorities. Current processes prevailing in the area visibly lead to the slow but constant death of anabranches, which may eventually cause a shift of the river type into a single channel belt and the loss of its unique multi-channel nature [16]. Although the unique riparian wetlands and their water balance have been recognized and modelled by Szporak-Wasilewska et al. [17], little is known about the hydromorphological processes prevailing in the area. The necessity of protection in the face of its anastomosing nature loss is unquestionable. However, the efficient protection of the anastomosing nature of the river requires, among other measures, detailed recognition of its current and historical hydromorphological state [18-20].

From the environmental management point of view, the conservation of anastomosing and all other types of rivers and their floodplains constitutes a great challenge, and their protection is an international priority [2123]. Systematic conservation planning aims to identify priority areas and activities that comprehensively, adequately, and efficiently protect particular subjects (i.e., species, habitats, biodiversity, river planform, etc.). To achieve this goal, park authorities may undertake one of two opposite strategies: hands-off or hands-on. The first, in its simplest form, is not taking action that manipulates or controls the conditions, components, or processes of an ecological system. The latter allows for implementing measures and activities, frequently standing in opposition to ongoing processes, oriented on the active protection of forms (in the case of the NNP — geomorphic features and anabranches). At present, NNP authorities are mostly implementing the hands-off strategy, focusing on simply the maintenance of processes. The key question is: where can this possibly lead? To address this question, the recognition of both geomorphic units and fluvial processes shaping the valley is highly required.

Rivers and floodplains are dynamic systems and they continuously adjust to changes in processes and human interventions. Their morphology is conditioned by flow regime, sediment yield, and valley characteristics that are controlled by factors operating at different spatial scales [24]. Climate and environmental factors operate at a catchment scale and since they control the inputs of matter and energy, any change in these variables leads unavoidably to a sequence of alterations and adjustments in the fluvial system, including the complete shift of their type [25]. Moreover, the hydromorphological nature of the river reaches depends not only upon interventions and processes within the reach, but also within the upstream and sometimes the downstream catchment [20]. Therefore, the method used for hydromorphological assessment should be focused on investigating the characteristics at different spatial scales, additionally giving insight into the historical state of the river system. Among several methods developed in different countries during the last decade, the hierarchical framework tool (HF) satisfies these terms and has been used in this study.

Against this background, the objectives of this study are: 1) determining the current hydromorphological state assessment of the Upper Narew River at different spatial scales and 2) conducting a historical investigation of the river planform within the NNP. In the study, a tailored HF method [20] elaborated upon in the European Restoring River for Effective Catchment Management (REFORM) project was used for investigating hydromorphology and the documentation of changes in the number of channels (i.e., anabranches) within the anastomosing section of the NNP over time.

\section{Experimental}

\section{Materials and Methods}

\section{Study Area}

The Narew is a lowland low-energy river in northeastern Poland (Fig. 1). It drains an area of $75,000 \mathrm{~km}^{2}$, partly located in Belarus, and is a right-hand tributary of the largest river in Poland, the Vistula. The catchment is located in a temperate climatic zone with moderately warm summers (mean temperature in July $18^{\circ} \mathrm{C}$ ), cool winters (mean temperature in January $-2^{\circ} \mathrm{C}$ ), and an annual average precipitation total of ca. $600 \mathrm{~mm}$. A part of the river valley between Suraż and Rzędziany (ca. $35 \mathrm{~km})$ forms the NNP $(6,810 \mathrm{ha})$, protecting the precious anastomosing stretch. Within the NNP, the river network consists of small interconnected channels within an unconfined valley. Vegetation cover within the NNP 


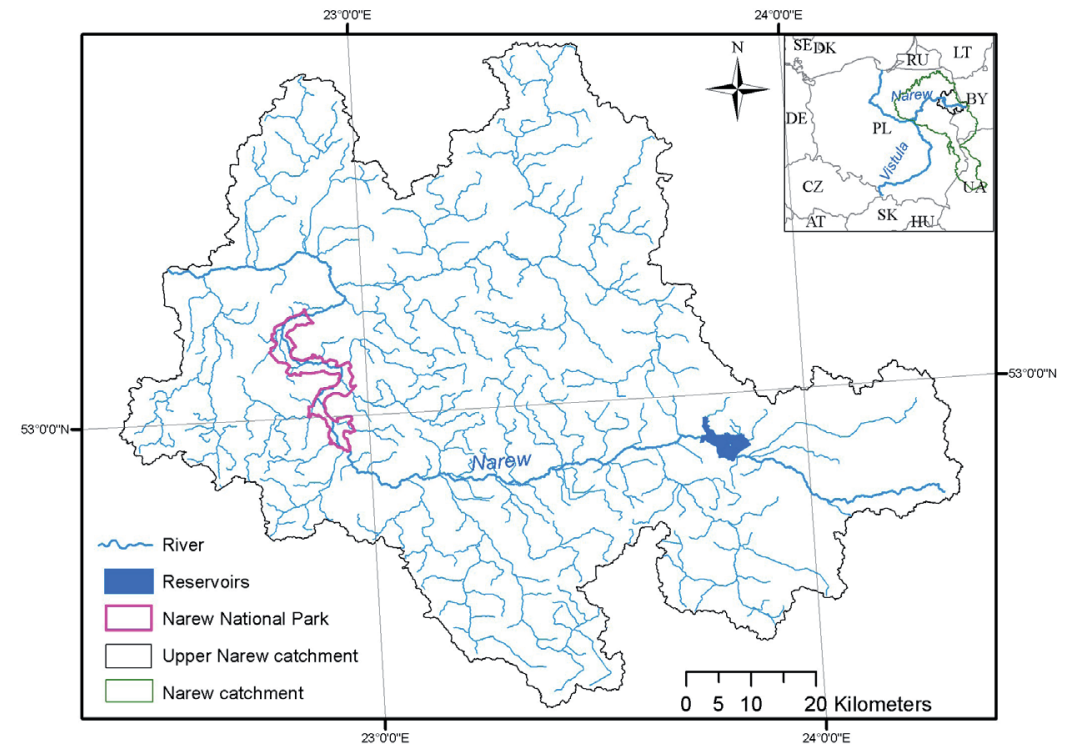

Fig. 1.Case study location.

is predominantly made up of early growth reed and sedge communities, which have long been managed for reed harvesting [26].

\section{Hierarchical Framework}

The study applies a tailored HF method [20] that relies on the multi-scale approach for investigating hydromorphology and focuses on the geomorphological characteristics and the hydrological and geomorphological processes that influence the nature and dynamics of river channels and their floodplains across time and space. A significant advantage of the method lies in its open-ended nature, which allows elements of the framework methodology to be adapted to local conditions [27]. The method consists of three main stages: 1) delineation of spatial units, 2) their characterization with respect to a defined set of

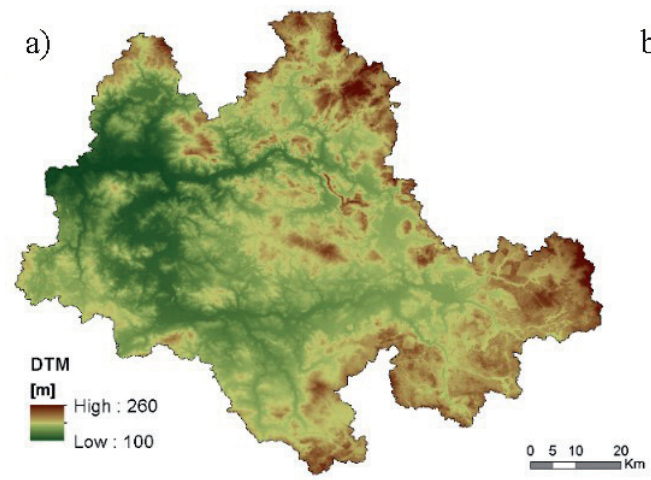

b)
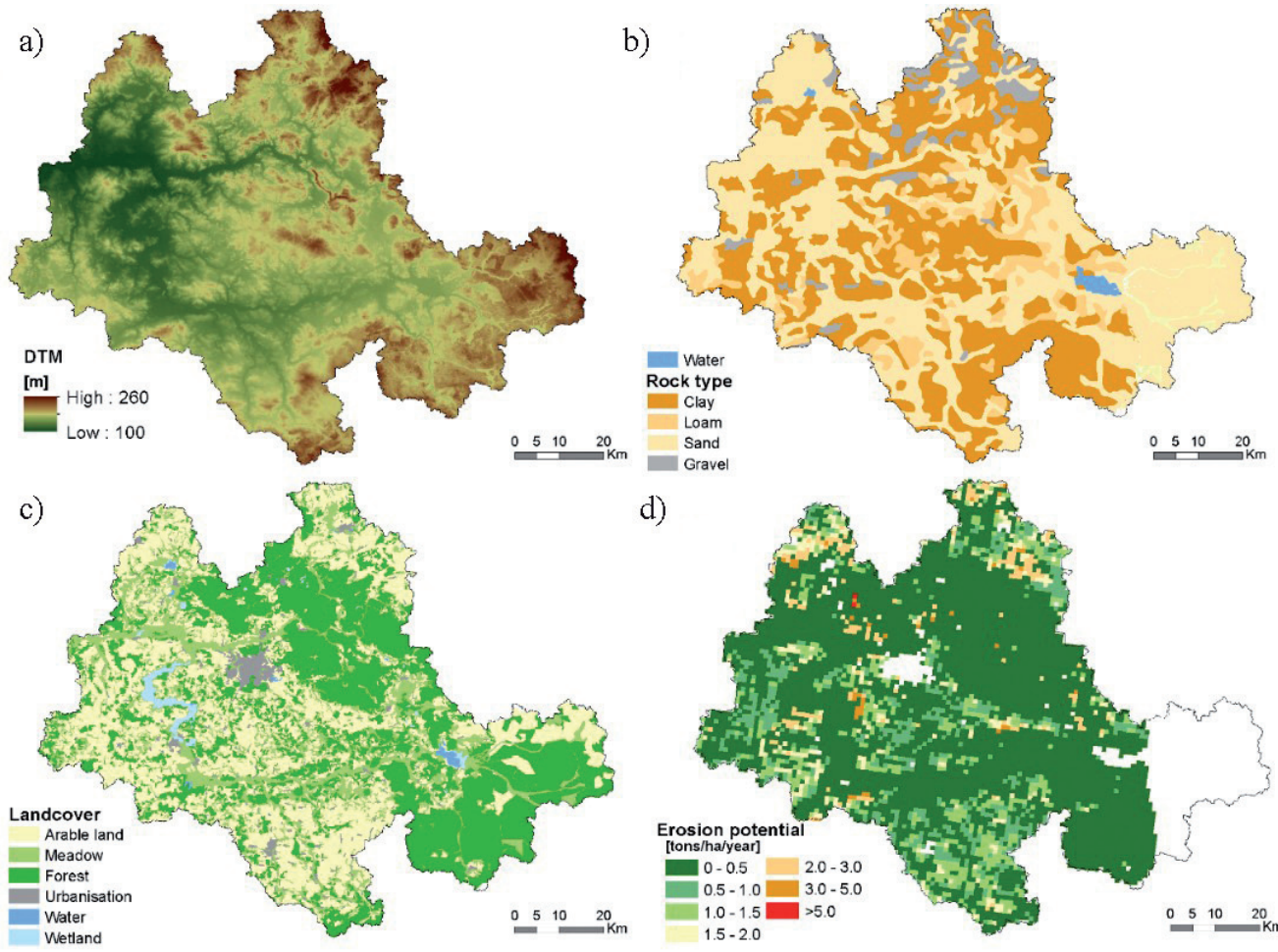

d)

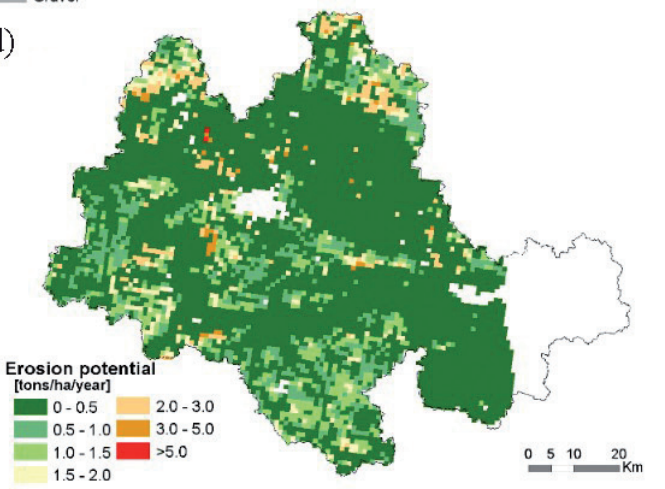

Fig. 2. Datasets used in the delineation stage of catchment and landscape units, a) Digital Elevation Model, b ) Geological map, c) Land cover map, d) Rate of erosion. 
Table 1. List of characteristics used in current hydromorphological state assessment for the NNP.

\begin{tabular}{|c|c|c|c|c|}
\hline $\begin{array}{l}\text { Spatial } \\
\text { scale }\end{array}$ & Category & Characteristic type & Data type & Data source \\
\hline \multirow{4}{*}{$\begin{array}{l}\text { Catchment } \\
\text { and } \\
\text { landscape } \\
\text { unit }\end{array}$} & Geology & Rock types & $\begin{array}{c}\text { Polish Geological Map } \\
\text { 1:500 } 000\end{array}$ & PIG-PIB \\
\hline & Land cover & Land cover structure & CLC 2012 & GIOŚ \\
\hline & Rainfall & Daily sum of precipitation & 20 precipitation gauges & IMGW-PIB \\
\hline & Sediment & Sediment delivery potential & PESERA & $\begin{array}{l}\text { http://eusoils.jrc. } \\
\text { ec.europa.eu }\end{array}$ \\
\hline Segment & Flow regime & Daily flow characteristics & 1 river gauging station & IMGW-PIB \\
\hline \multirow{9}{*}{ Reach } & \multirow{2}{*}{$\begin{array}{l}\text { Channel } \\
\text { geometry }\end{array}$} & Channel gradient & DEM 1meter resolution & CODGIK \\
\hline & & Channel width and depth & $\begin{array}{l}\text { Ortophotos, } \\
\text { Field surveys }\end{array}$ & $\begin{array}{l}\text { http://www.geoportal. } \\
\text { gov.pl/ }\end{array}$ \\
\hline & \multirow[b]{2}{*}{$\begin{array}{l}\text { Channel } \\
\text { planform }\end{array}$} & $\begin{array}{l}\text { Sinuosity index - measured based on the axis } \\
\text { of the overall planimetric river course }\end{array}$ & Ortophotos & $\begin{array}{l}\text { http://www.geoportal. } \\
\text { gov.pl/ }\end{array}$ \\
\hline & & $\begin{array}{l}\text { Anabranching index - quantified at cross } \\
\text { sections spaced } 0.5-1 \text { times the maximum } \\
\text { width of the outer wetted channels, and for all } \\
\text { channels (artificial or natural) that regularly } \\
\text { carry water and are connected to another } \\
\text { channel at both their upstream and down- } \\
\text { stream ends. }\end{array}$ & Ortophotos & $\begin{array}{l}\text { http://www.geoportal. } \\
\text { gov.pl/ }\end{array}$ \\
\hline & \multirow{2}{*}{ Vegetation } & Riparian corridor structure & Vegetation map & NNP \\
\hline & & Aquatic vegetation & Field surveys & - \\
\hline & $\begin{array}{l}\text { Physical } \\
\text { pressures }\end{array}$ & Number and type of physical pressures & $\begin{array}{c}\text { Topographic Objects } \\
\text { Database, } \\
\text { Field surveys }\end{array}$ & $\begin{array}{l}\text { http://www.geoportal. } \\
\text { gov.pl/ }\end{array}$ \\
\hline & \multirow{2}{*}{$\begin{array}{l}\text { Morpho-logical } \\
\text { elements }\end{array}$} & Channel geomorphic elements & $\begin{array}{l}\text { Ortophotos, } \\
\text { Field surveys }\end{array}$ & $\begin{array}{l}\text { http://www.geoportal. } \\
\text { gov.pl/ }\end{array}$ \\
\hline & & Floodplain geomorphic elements & Ortophotos & $\begin{array}{l}\text { http://www.geoportal. } \\
\text { gov.pl/ }\end{array}$ \\
\hline
\end{tabular}

Abbreviations: CLC - Corine Land Cover, CODGiK - Central Agency for Geodetic and Cartographic Documentation, DEM- Digital Elevation Model, GIOS - Chief Inspectorate of Environmental Protection, IMGW-PIB - Institute of Meteorology and Water Management - National Research Institute, NNP - Narew National Park, PIG-PIB - Polish Institute of Geology - National Research Institute

parameters, and 3) documentation of historical changes of the fluvial system. The delineation stage is carried out with the support of GIS tools in order to delineate catchment, landscape units, river segments, and river reaches. Following the recommendations on how to delineate particular spatial units [20], each was distinguished as follows:

- Catchment: area of land drained by a river and its tributaries delineated based on a topographical divide; data source: Digital Elevation Model (DEM) at $1 \mathrm{~m}$ resolution (Fig. 2a).

- Landscape unit: portion of a catchment with similar landscape morphological characteristics delineated based on elevation, relief-dissection, land cover, geology, and erosion potential; data source: DEM, geological map 1:500,000 (Fig. 2b), Corine Land Cover 2012 (Fig. 2c), PESERA model $1 \mathrm{~km}$ resolution (Fig. 2d).

- Segment: section of a river subject to similar valleyscale influences and energy conditions delineated based on major changes of valley gradient, tributary confluences, and valley confinement; data source: DEM.

- Reach: section of a river along the boundary of which conditions are sufficiently uniform so that the river maintains a near consistent internal set of processform interactions delineated based on channel planforms, changes in channel slope, and artificial discontinuities.

The characterization of spatial units is conducted in order to support the understanding of the current conditions and functioning of the fluvial system. Properties for different spatial units are characterized using existing datasets and, in general, this process involves identifying the datasets that contain relevant information allowing for a detailed description and identification of the processes and forms. The current hydromorphological state of the NNP has been assessed based on the modified list of parameters proposed in HF (Table 1). 
The crucial stage of analysis concerns the detection of any channel planform changes in history, most commonly evidenced by historical maps or aerial imagery. This stage proves whether the current hydromorphological state deteriorated or improved over time and might help to understand the current processes ongoing at different spatial scales and the potential evolutionary trajectory of further changes. In this study, historical maps and aerial photographs were used to examine changes in the channel planform and width over time. For Poland, the earliest reliable records of a channel planform are usually provided by the Map Archive of the Military Institute of Geography (polski.mapywig.org). For the NNP area, a map from 1900 at 1:100,000 scale was used to document the earliest channel setting. Additionally, aerial photographs at 1:10,000 scale for 1966, 1997, and 2013 were acquired from the Main Geodetic and Cartographic Documentation Center. The historical map as well as aerial photographs were manually georeferenced in ArcGIS based on common landmarks (i.e., junctions, streets, railways). Afterward, all channels of the Narew River within the NNP were digitized for each time point. The channel area and length were quantified and used to calculate the average channel width separately for the main and side channels. To evaluate the development of the system, the anabranching index ( $\mathrm{Ai}$ - the number of active channels at the baseflow separated by vegetated islands) was calculated for each time point.

\section{Results and Discussion}

\section{Spatial Units Delineation}

In the Upper Narew catchment two landscape units (LU) were delineated based on the dominating land cover type with the prevailing share of forests in the upstream (LU1) and arable lands in the downstream part (LU2). No significant patterns of catchment topography, erosion potential, and geology were found, and hence no additional divisions based on these characteristics proceeded. The upper course of the Narew was delineated into 7 segments based mainly on the significant increase in the catchment area at major tributary confluences (subcatchment area of the tributary greater than $20 \%$ of the main stem catchment area upstream of the junction). The longitudinal profile of the entirely unconfined river indicated a low and constant gradient (Fig. 3). An additional segment (S2) was delineated for the Siemianówka reservoir (11 km of river length), due to a specific major influence on the flow regime. The part of the Narew River was delineated into 35 homogenous river reaches. The main criteria of the division was based on the channel planform and the presence of artificial structures. The river at its length is characterized by a large variety of channel planforms among which straight, sinuous, meandering and anastomosing reaches can be found. All spatial units delineated in the Upper Narew catchment are presented in Fig. 4. Given the scope of this study, the further characterization of spatial units is focused on the most precious anastomosing river reach within the NNP and the river segment in which it is located (S6, Fig. 4).

\section{Spatial Units Characterization}

\section{Catchment}

The Upper Narew catchment is a large, lowland, siliceous catchment according to the Water Framework Directive typology [28] (catchment area $=6,656 \mathrm{~km}^{2}$, mean elevation $=149.5 \mathrm{~m}$ a.s.1.) and is entirely occupied by siliceous bedrock. Dominant types of soil are pure and loamy sands, while very heavy impermeable soils (clay, clay loam, silt loam) are rare in the landscape. The main valley bottoms are filled with peat deposits from the Holocene. The landcover in the Upper Narew catchment is predominantly agricultural (53.4\%), with arable lands composing $39 \%$ and pastures the remaining $14.4 \%$. The second most important land use by area is forests (39.5\%). Urban areas and waters cover $7.1 \%$ of the catchment. The largest structure that influences riverflow and significantly alters its regime is a dam located at $367 \mathrm{~km}$ of the Narew River that creates Siemianówka Reservoir. Construction was finished in 1990, and in 1992 it was completely filled with water.

\section{Landscape Unit}

LU2, with a total area of $5,288 \mathrm{~km}^{2}$, is mainly occupied by agricultural areas $(62.5 \%)$, which strongly dominate over forests (33.2\%) and urbanized areas (2.9\%). Historical precipitation records from 20 rainfall gauging stations (acquired from IMGW-PIB) for the period 1951-2012 were used to describe monthly and yearly rainfall statistics. As presented in Fig. 5, the highest precipitation rates occur in May-October $(65 \mathrm{~mm}$ on average), whereas the lowest were in November-April ( $35 \mathrm{~mm}$ on average). The average yearly precipitation sum $(600 \mathrm{~mm})$ for the LU2 falls into the range characteristic for the entire country [29]. What is noteworthy is that during the summer months extremes occur most frequently, which means that, depending on the year, either maximum or minimum precipitation rates can be observed. Such great amplitude visible in the graph is characteristic of catchments under continental climate influence [30]. Fine sediment erosion rates are very low in the catchment as compared to the range across Europe ( 0 to $>50$ tons ha $^{-1}$ year ${ }^{-1}$, PESERA), as the average rate equals 0.03 tons ha ${ }^{-1}$ year ${ }^{-1}$.

\section{Segment}

The flow regime analysis was based on daily flow data records from the Suraż gauging station (located several kilometers upstream from the anastomosing reach) acquired from IMGW-PIB. The time period covered by datasets spanned from 1951 to 2012. The hydrograph of average monthly flows falls into the characteristic 


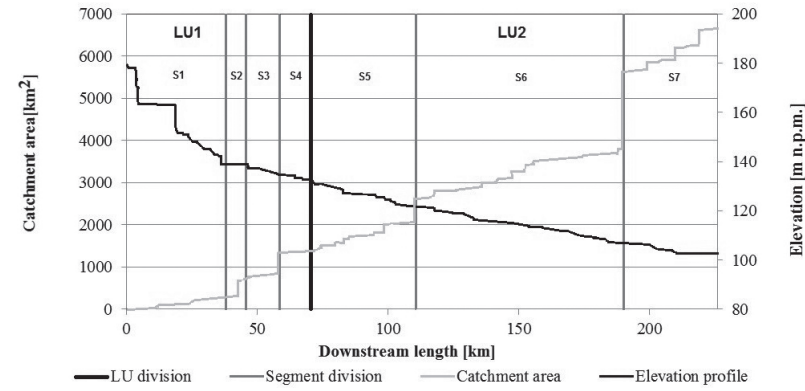

Fig. 3. Longitudinal profile across the upper course of the River Narew with division units.

pattern for lowland snow/rainfall-fed rivers with clearly dominating spring flooding, sourced by snowmelt occurring most commonly in April (Fig. 6). Other significantly lower floods appear during the summer and are caused by heavy rain events. The average yearly discharge for the analyzed period equals $15.4 \mathrm{~m}^{3} \mathrm{~s}^{-1}$, whereas extreme events (i.e., minimum and maximum flows) equal $1.5 \mathrm{~m}^{3} \mathrm{~s}^{-1}$ and $250 \mathrm{~m}^{3} \mathrm{~s}^{-1}$, respectively. Additionally, morphologically representative discharges were calculated based on yearly annual peak flows at return periods of $2(\mathrm{Qp} 2)$ and $10(\mathrm{Qp} 10)$ years. Statistics indicate that they equal 64 and $122 \mathrm{~m}^{3} \mathrm{~s}^{-1}$ for Qp2 and Qp10, respectively. The number of days with flooding was diverse for the past 60 years (from 0 to 119 and 37 on average) and depends majorly on the snow cover thickness from the winter season.

\section{Reach}

The anastomosing reach within the NNP is a multithread, unconfined river stretch with a very high

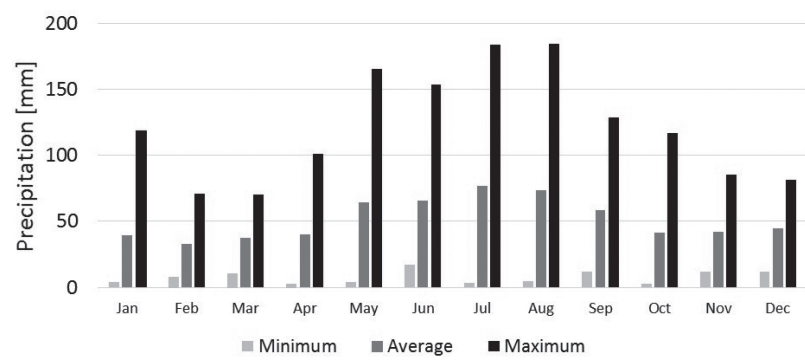

Fig. 5. Precipitation statistics for LU2 (average values from 20 rainfall gauging stations).

anabranching index (4.1) and a moderate sinuosity index for the main channel (1.3). The average channel gradient for the delineated $35 \mathrm{~km}$-long reach equals $0.0002 \mathrm{~m} \cdot \mathrm{m}^{-1}$, and the average total channel width in the valley transect reaches $40 \mathrm{~m}$ (main channel $24 \mathrm{~m}$, anabranches $16 \mathrm{~m}$ ). The low width/depth (W/D) ratio varying from 2 to 4 in the analyzed reach is characteristic of the investigated channels. The riparian corridor vegetation structure is dominated by reed communities (Phragmition) occupying $35 \%$ and sedge communities (Magnocaricion - also covering $35 \%$ of the valley). In this system, such vegetation would be considered pioneer type, eventually succeeded by trees and shrubs [26]. Mature trees and scrubs (Alnetea glutinosae) cover only $15 \%$ of the NNP area (mostly at the edges of the valley), whereas the remaining $15 \%$ is occupied by grass (Molinio-Arrhenatheretea; Fig. 7). Due to lack of artificial embankments at the entire reach length, the riparian corridor is subject to inundation whenever the bankfull discharge is exceeded. This ensures undisturbed connectivity of the river and valley, as well as the longitudinal continuity of the water and sediment flow.

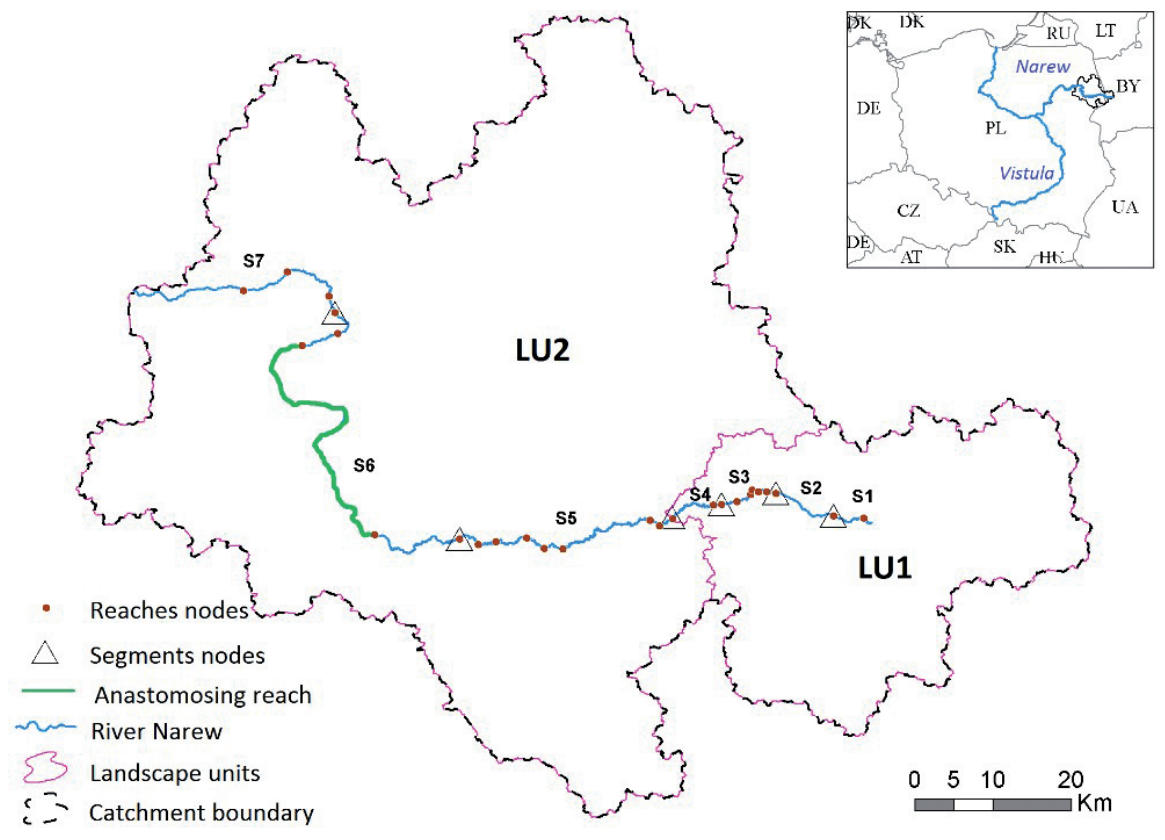

Fig. 4. Spatial units delineated in the Upper Narew catchment. 


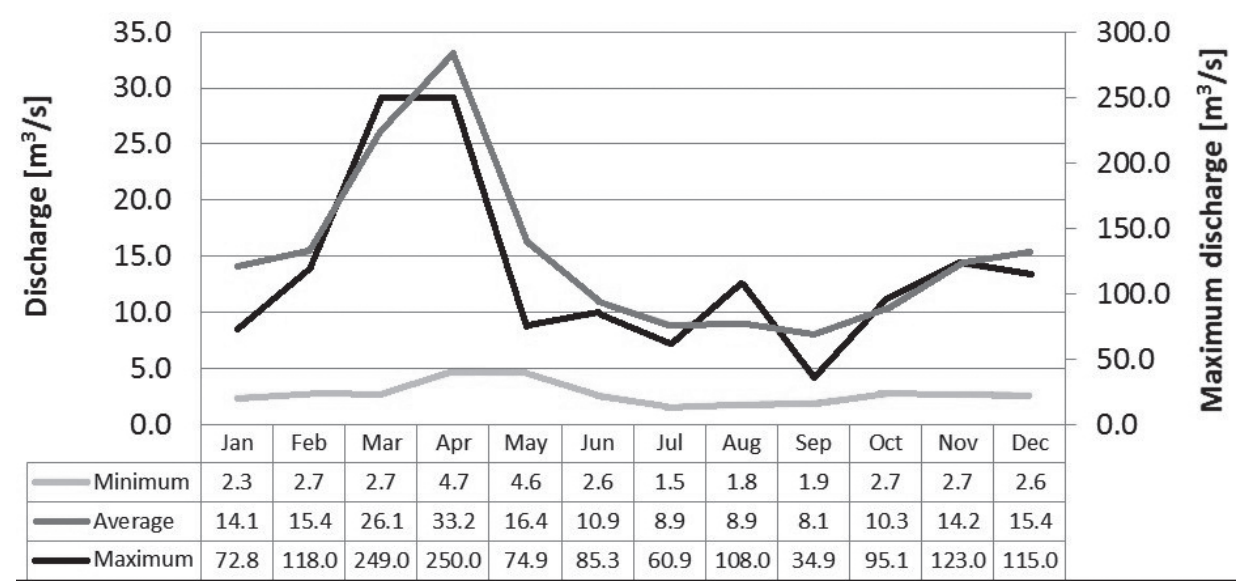

Fig. 6. Flow statistics for the Suraż gauging station.

The abundance of aquatic vegetation in the river channels depends on water depth and current velocity. Active channels deeper than $2 \mathrm{~m}$ are free of vegetation, but shallower stretches are promptly colonized by both emergent and submerged macrophytes.

In the Narew River, the banks of the anastomosing reaches are usually very steep or nearly vertical and extremely resistant to erosion because of the stabilizing force of the peat layer and plant roots. Where this does occur, bank erosion is identified by the presence of peat blocks within the channel. However, this occurs only exceptionally within the anastomosing reaches in a few short sections along the banks. This indicates that the protective nature of riparian vegetation, erosion resistance of the peat layer, and low specific stream power result in the negligible lateral erosion of the Narew channels and lateral stability of the internode reaches of the river.

Due to the low sediment delivery potential and resistance to erosion banks, channel geomorphic elements created by the erosive and depositional activity of flowing water (i.e., mid-channel bars, side bars, point bars) are extremely rare in the anastomosing section of the NNP. For the same reason, specific floodplain geomorphic units (ox-bow lakes) are practically not formed in the valley, and exclusively abandoned channels are reported to prevail in the area. The GIS calculations based on the orthophotos indicate that $110 \mathrm{~km}$ of cut-off anabranches are present within the NNP floodplain.

No artificial structures (i.e., embankments) and riverbed or bank reinforcements or modifications were observed over the entire length of the analyzed reach. A weir with regulated crest is present only at the downstream part of the NNP, which was constructed in 1995 in order to slow the water outflow from the anastomosing section of the NNP, after the adjacent downstream $7 \mathrm{~km}$-long section of the river was regulated in 1970. Among the floodplain artificial structures, 3 embanked roadways across the valley were constructed. Cartographic evidence from several sources shows these $50-\mathrm{m}$ wide earthen ridges appearing in the late $19^{\text {th }}$ century.

\section{Current Hydromorphological Processes}

A process-based description of the investigated characteristics at different spatial scales (Fig. 8) is an important element of identifying and understanding the current hydromorphological status of a river as well as the direction of potential future changes with this respect. Key hydromorphological processes at the catchment scale are water and sediment production, which control bio-physical processes, channel dimensions, and patterns along the drainage network [27]. The Upper Narew River catchment is a siliceous lowland catchment composed entirely of permeable soils. The dominant land cover types are agricultural lands and forest, whereas the urbanized areas are marginal. These characteristics determine the low sediment production and annual runoff pattern, which is devoid of rapid rain-event driven peaks that are most commonly mitigated and delayed due to high soil retention. The most significant factor that disrupts the natural water runoff is the large reservoir (Siemianówka) constructed in 1992 in the upstream part of the Upper Narew catchment.
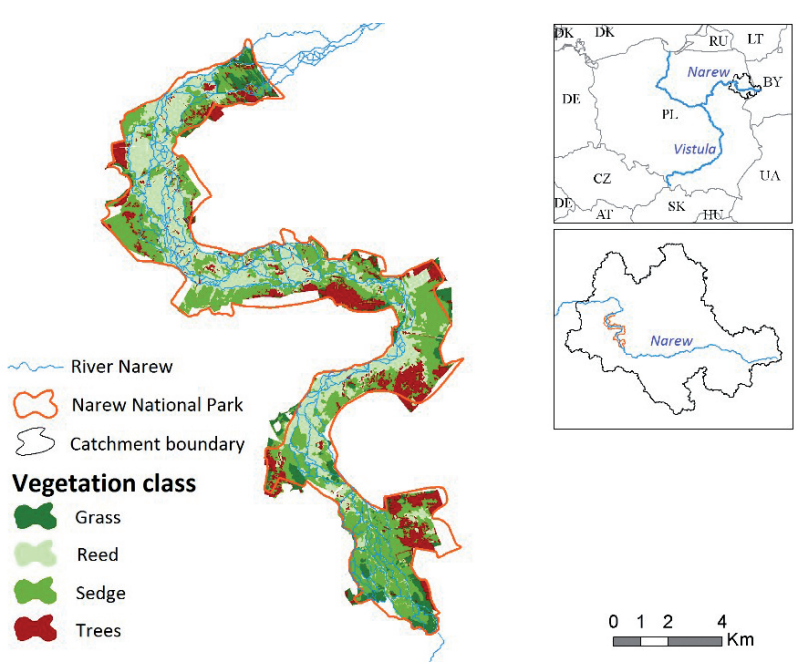

Fig. 7. Map of the riparian corridor vegetation in the NNP. 


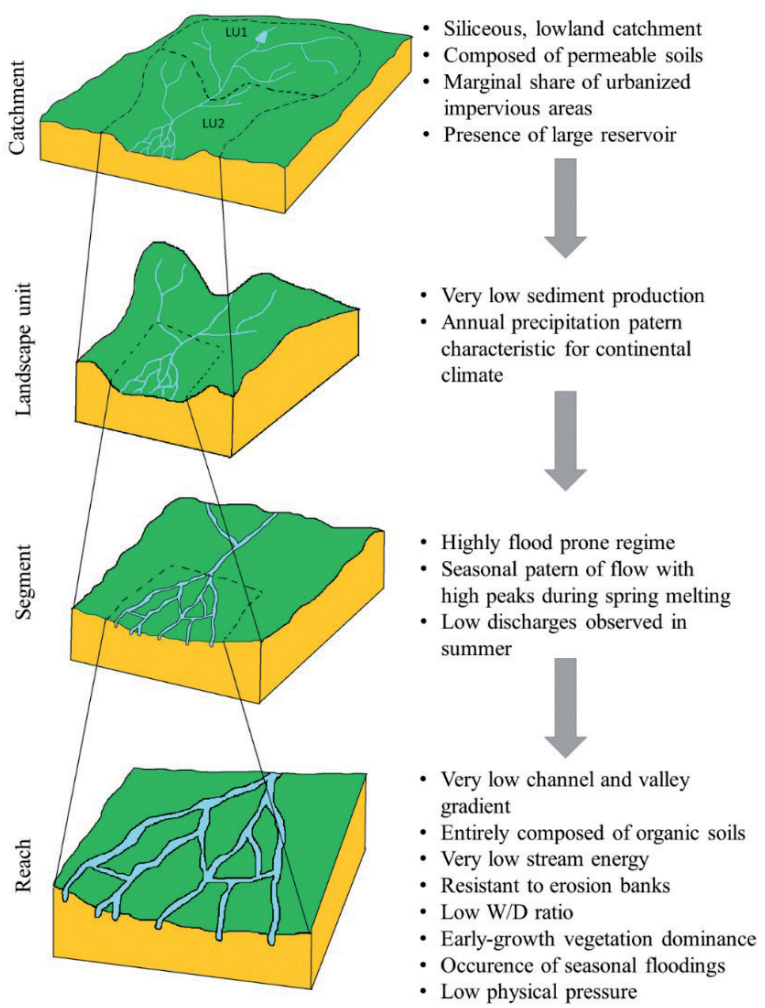

Fig. 8. Hierarchy of spatial scales for the assessment of river geomorphology with their major characteristics.

Due to relatively homogenous topography within landscape units, hydromorphological indicators are described in order to provide more detailed information on runoff processes and sediment production. Soil erosion rates indicate the production of sediment that may reach the river network and influence the hydromorphological nature and river dynamics at the finer spatial scales.
In the studied catchment sediment production in LU2 estimated based on the PESERA model seem to be extremely low (0.03 tons $\mathrm{ha}^{-1}$ year $\left.{ }^{-1}\right)$. Precipitation reaching $600 \mathrm{~mm}$ yearly on average from which $1 / 4$ is transformed into runoff and $3 / 4$ is evapotranspired (calculated as an average value based on daily flow records from the Suraż gauging station and precipitation records). This water production potential in combination with permeable soils and land cover does not generate a high surface erosion potential, as the dominant runoff path is related to interflow.

Key processes at the river segment are predominantly related to the flow regime. Indicators of hydromorphological processes at this scale inform flow properties that control river energy and the potential of flooding. In the investigated segment, daily flow records reflect the nature of the river that is subject to inundation most frequently during the spring melting season. Other, substantially lower, rain-event driven floods occur occasionally in the summer. Likewise, in summer, when precipitation does not occur for weeks and evapotranspiration is high, extremely low water stages are observed; however, the river does not dry up entirely as it is constantly contributed to by the baseflow component.

At the reach scale, the key hydromorphological processes are related to a lateral and vertical hydrological exchange within riparian and flooding zones, and the local channel adjustments that may occur in response to the flow and sediment regime changes or human intervention. The investigated reach within the NNP, as described at coarser spatial scales, has low sediment delivery potential, and the flow regime typical for lowland catchments composed of permeable soils is highly contributed to by interflow and baseflow. The reach itself is characterized by an unconfined river valley almost entirely vegetated by early-growth reeds and

Table 2. Characteristics of the present condition of NNP anastomosing system.

\begin{tabular}{|c|c|c|c|c|}
\hline Characteristics & $\begin{array}{c}\text { Condition according } \\
\text { to HF }\end{array}$ & NNP state & Fulfillment & Remarks \\
\hline Low gradient & $<0.005$ & 0.0002 & YES & - \\
\hline $\begin{array}{l}\text { Vegetation - early growth, } \\
\text { sedges, reed }\end{array}$ & required & $\begin{array}{l}\text { reed communities }(41 \%) \text {, grass } \\
(26 \%) \text { sedge communities } \\
(22 \%)\end{array}$ & YES & - \\
\hline Organic soils (peat) & required & $\begin{array}{l}\text { Whole valley bottoms filled } \\
\text { with peat deposits from the } \\
\text { Holocene }\end{array}$ & YES & - \\
\hline Low stream energy & $<10 \mathrm{~W} \mathrm{~m}^{-2}$ & $2-3 \mathrm{~W} \mathrm{~m}^{-2}$ & YES & - \\
\hline Low sediment potential & $<0.1\left(\right.$ tons ha ${ }^{-1}$ year $\left.^{-1}\right)$ & $0.03\left(\right.$ tons ha ${ }^{-1}$ year $\left.^{-1}\right)$ & YES & Based on PESERA model \\
\hline Seasonal floodings & required & $\begin{array}{c}\text { Mean annual number of days } \\
\text { with flooding - } 37\end{array}$ & YES & $\begin{array}{l}\text { Calculated for period } 1951 \text { - } \\
2012 \text { based on Q observations } \\
\text { from Suraż gauging station }\end{array}$ \\
\hline $\begin{array}{l}\text { Steep, resistant to erosion } \\
\text { banks }\end{array}$ & required & $\begin{array}{c}\text { Present in the whole river } \\
\text { system }\end{array}$ & YES & - \\
\hline Low $\mathrm{W} / \mathrm{D}$ ratio & $<10$ & $2-4$ & YES & - \\
\hline
\end{tabular}


sedges. The valley bottom is filled with organic soils, which make channel banks extremely resistant to lateral erosion. Erosion-resistant banks control channel lateral migration and limit the ability of the channel to adjust gradually to the temporal and spatial changes in the flow and sediment conditions. The inability of channels to alter their capacity after frequent or high-magnitude flooding is a precondition for avulsion and the possible formation of new channels elsewhere on the floodplain [31]. The low channel and valley gradient of the analyzed reach is assumed to favor anabranch formation as a mechanism by which the river can adjust to increase its flow efficiency. Another crucial factor present in the reach and necessary for the development of anabranches is bank stabilization due to the growth of riparian vegetation, which effectively confines the channel [32-33]. Highly variable flood-prone flow in the reach characterized by the occurrence of spring high water stages is a crucial factor in the anabranching formation [7]. The occurrence of the high-water stage eventually exceeding the bankfull discharge and local flow disturbances caused by blocking structures (vegetation) leads to an overflow of water on the predisposed side of the channel and may eventually form a new channel [12]. Table 2 lists all the mutual characteristics reported worldwide that encourage avulsion and might be crucial in anabranch formation and maintenance. All the characteristics are fulfilled in the NNP, which can lead to the conclusion that the processes are favorable for anastomoses self-maintenance and preliminarily justify the hands-off strategy undertaken by the NNP Authorities. In order to ultimately confirm or deny it, a historical channel planform investigation has been made and the results are presented in the following section.

\section{Channel Planform Changes}

The anastomosing section of the Narew in the NNP has changed significantly over the past 100 years (Fig. 9). More than $110 \mathrm{~km}$ of anabranches have disappeared from the river network. However, the response is not uniform across the anastomosed reach. Higher rates of channel extinction are evident in the southern part of the system (near the upstream border of NNP), and lower rates of loss are in the central and northern parts of NNP. The differences in extinction rates are also evident over time, and an increasing trend can be noted. In the first time period (1900-1966) the loss equaled $0.53 \mathrm{~km}_{\text {year }}{ }^{-1}$,

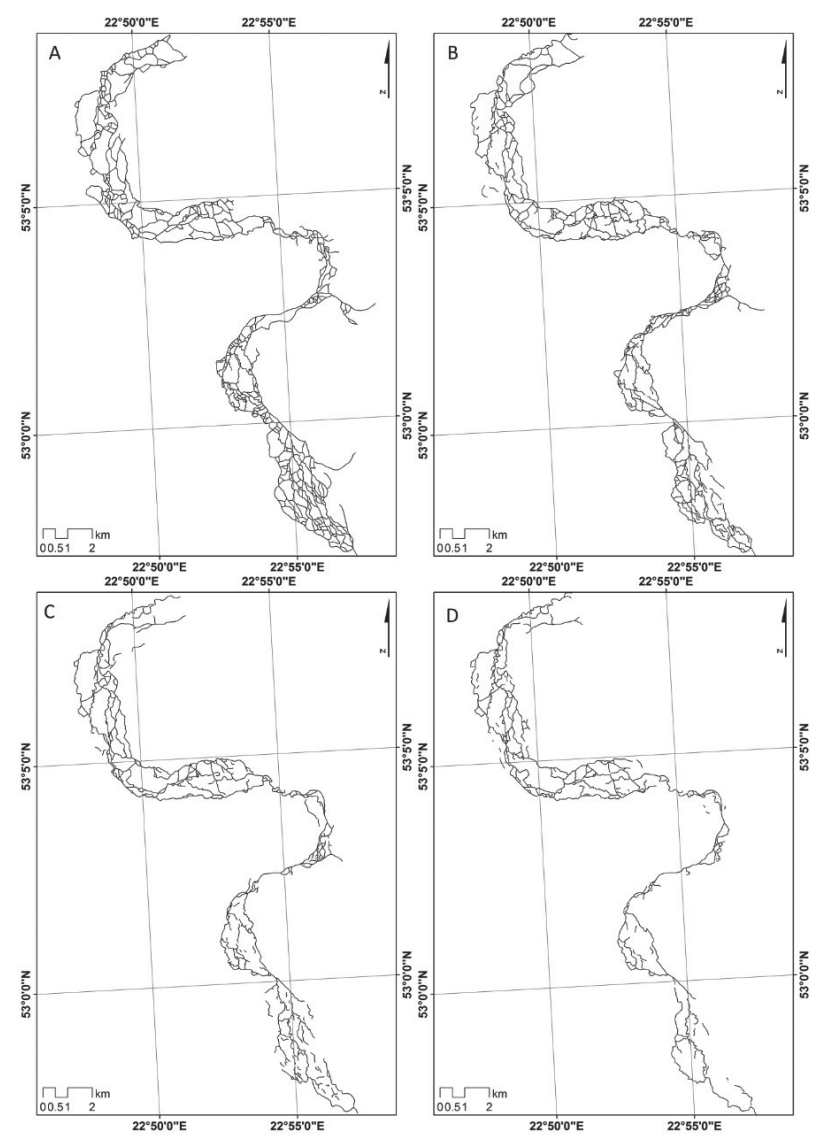

Fig. 9. Channel network digitized from historical maps and aerial photographs of the River Narew in the Narew National Park at different time points: 1900 (A), 1966 (B), 1997 (C), 2012 (D).

increasing in 1966-1997 to $1.45 \mathrm{~km}$ year ${ }^{-1}$ and increasing yet again in 1997-2013 (2.26 km year $\left.{ }^{-1}\right)$. The analysis of channel width (Table 3) indicates that the width of the main channel relative to total channel width in each cross-section has almost doubled since 1966 (31\%) to $2012(61 \%)$. Unfortunately, no significant data on channel depths was available. Nevertheless, the width analysis suggests that the main channel has increased in capacity concurrently as side channels become dominant. Compelling findings from the aerial imagery investigation were noted, proving the lateral stability of the anastomosing channels drained in organic soils [34]. The difference in the thalweg course between the corresponding (not extinct) river channels was not greater than one meter from 1966 to 2012.

Table 3. Statistics for channels evolution in the NNP.

\begin{tabular}{|c|c|c|c|c|c|}
\hline Year & $\begin{array}{c}\text { Width }(\mathrm{m}) \\
\text { (main channel) }\end{array}$ & $\begin{array}{c}\text { Width }(\mathrm{m}) \\
\text { (side channels) }\end{array}$ & $\begin{array}{c}\text { Share of main channel } \\
\text { width in total width }\end{array}$ & Anabranching index & Length (km) \\
\hline 1900 & No data & No data & No data & 5.54 & 274.7 \\
\hline 1966 & 22.9 & 51.3 & $31 \%$ & 4.81 & 239.8 \\
\hline 1997 & 24.1 & 31.4 & $43 \%$ & 4.05 & 194.1 \\
\hline 2012 & 24.6 & 16 & $61 \%$ & 3.08 & 160.2 \\
\hline
\end{tabular}




\section{Hydromorphological Assessment}

Different hydromorphological characteristics have been identified in the Upper Narew catchment at different spatial units. The HF concept of processbased understanding of river hydromorphology required coupling the indicators with hydromorphological processes on which they interact [27]. At the coarser spatial scale (catchment, landscape unit) indicators such as geology, land cover, and precipitation significantly govern hydrological processes (i.e., surface runoff, interflow, baseflow), which are crucial in sediment production and delivery, and determine the river flow patterns [35-39]. At the finer scale (segment, reach), hydromorphological processes and functioning of the river ecosystem are greatly influenced, among other factors, by flow regime [40], riparian vegetation [20], and local valley settings [41]. The hierarchical approach applied in the Upper Narew catchment allowed for interpreting the influence of selected indicators on current hydromorphological processes that in turn gave an overall understanding of the current condition of the anastomosing reach in the NNP. As shown in the Results section cascade of processes, beginning from low sediment delivery potential and moderate annual precipitation, determining the low stream sediment loads and moderately diverse flow regime, with one major flooding every year. As a consequence, the Upper Narew River, like other lowland rivers with a dominating slow current, have more stable banks and beds, and thus morphological changes occur in them very slowly [42-43]. The further cascade of erosion and sediment transport processes in the reach, conditioned by the processes from the coarser scale, is responsible for the final shape of the interconnected stream network of the NNP. A very low channel gradient and stream energy as well as erosion-resistant banks lead to very low erosion rates and negligible lateral migration of channels [8,31]. This, in turn, secures the relative stability of the anastomoses. The constant occurrence of seasonal flooding that shapes the natural vegetation in the valley ensures the natural character of the NNP, which has been protected since 1996 through the hands-off protection plan undertaken by the park authorities.

\section{Historical Planform Changes}

The reach valley conditions accurately listed in Table 2 seem to be preferential for triggering the avulsion process $[8,10,12]$. However, the historical planform changes indicated contrary findings. The analysis of river planform based on maps and aerial photographs at certain points of time clearly showed a slow (at the beginning of the $20^{\text {th }}$ century) and gradually accelerating pace of channel extinction. Since geology is deemed a permanent physical control of hydrological processes on a broad scale and does not change substantially over the timescales under consideration, it is not included as a potential cause of extinction. Other studies investigating land cover and precipitation changes in the Upper Narew catchment covering the analyzed time period did not indicate any significant alterations. The current land cover structure compared with the state from 1885 changed by 1-3\% on average for the attributed classes [44]. Marcinkowski et al. [16] analyzed the precipitation and river flow pattern for the Upper Narew catchment for 1950-2000 and indicated rather constant trends of the variables, which were broken exclusively for 14 years (1969-1983), when a slight increase in precipitation and discharge were noted. Therefore, the most possible drivers of channel morphology change are related to alterations at the reach scale. Marcinkowski et al. [16] proved that the rates of anabranch loss increased when the number of pressures inhibiting anabranch creation and maintenance multiplied. The most crucial are: the cessation of the localized water level and channel management (timber rafting, fishing dams, and water mills), the loss of floodplain seasonal mowing, and infrastructure construction (embanked roads and an upstream dam). These all contribute to low water levels and flows, the deposition of sediment at anabranch inlets, the encroachment of common reed (Phragmites australis), and the eventual loss of anabranches.

\section{Management Challenges}

Presently, the Narew anastomoses in NNP are protected exclusively by a number of restrictions on activities within the park borders, with the expectation that natural hydro-geomorphic processes will maintain anabranches. To persist, anastomosing planform requires that either anabranch formation through avulsions is active or anabranch loss suppressed [2]. However, due to lower water levels and decreased flood frequency in the valley [16], it is unlikely that new anabranches will self-form via avulsion. The loss of anabranches in the NNP is rather irreversible under the current boundary catchment and reach conditions. Moreover, the handsoff approach to direct channel management will most likely result in a further loss of anabranches due to reed expansion and sedimentation, switching eventually the river from a multi- to single-thread river in the next decades. Although the anastomosing planform of the Narew was initiated and created through natural processes, it has been maintained through a long history of human use and modification of the river system [16]. In order to prevent the progressive loss of anastomoses, active preservation of the hydromorphological form should be prioritized. The hands-on protection strategy seems to be the most reasonable solution for the NNP to protect the anabranching system. However, there are still open questions regarding measures that should be undertaken in such a new protection strategy. It is a great challenge to elaborate efficient activities oriented on avulsion promoting and anastomosis maintenance, which would not make the system entirely artificial. Potential solutions should be focused on restoring high water levels and maintaining flows in anabranches, as well as the significant interactions between water levels, sediment 
deposition, and vegetation encroachment that determine flow efficiency and control anabranch loss.

\section{Conclusions}

This study investigated the currenthydromorphological conditions of an anastomosing river reach in NNP and recognized the historical changes of the river planform at the reach scale. It applied a tailored HF tool that is a suitable tool tracking river planform response to all historical alterations. NNP authorities implemented the hands-off strategy from the beginning, focusing on the maintenance of hydro-geomorphic processes with the expectation that this would not disturb anastomosis maintenance. Hydromorphological recognition in the first instance indicated that current processes seem to be preferential for triggering the avulsion process, which would mean that the NNP policy is successful. Nevertheless, the analysis of historical planform changes proved the extinction of the anastomosing nature of the river in the NNP. The anastomosing planform of the Narew was created through natural processes, but it has been maintained through a long history of human use and modification of the river system. The hands-off approach to direct channel management will most likely result in a further loss of anabranches, and hence a turn into the hands-on protection strategy seems to be necessary if the current anabranching nature of the Upper Narew in the NNP is to be maintained. A question on selection of the specific measures to be undertaken for anastomoses protection remains opened. As there are no similar studies dealing with the maintenance of the anastomosing rivers, further analysis including hydrodynamic modelling need to be undertaken in the study area to fill this gap.

\section{Acknowledgements}

We would like to thank the anonymous reviewer for the comments and suggestions that helped improve our manuscript. This paper is a product of research conducted within the REFORM collaborative project funded by the European Union Seventh Framework Programme under grant agreement 282656. Part of the research was financed by the National Science Center, Poland under grant agreement 2015/19/N/ ST10/01629.

\section{References}

1. SCHUMM S.A. Speculations concerning paleohydraulic controls on terrestrial sedimentation. Geological Society of America Bulletin 79, 1573, 1968.

2. MAKASKE B. Anastomosing rivers: a review of their classification, origin and sedimentary products. EarthScience Reviews 53, 149, 2001.

3. KLEINHANS M.G., DE HAAS T., LAVOOI E., MAKASKE B. Evaluating competing hypotheses for the origin and dynamics of river anastomosis. Earth Surf. Process. Landforms 37, 1337, 2012.

4. ANSEN J.D., NANSON G.C. Functional relationships between vegetation, channel morphology, and flow efficiency in an alluvial (anabranching) river, J. Geophys. Res. 115, 2010.

5. PHILLIPS J.D. Anastamosing channels in the lower Neches River valley, Texas. Earth Surf. Process. Landforms 39, $1888,2014$.

6. KOCH J.C., MCKNIGHT D.M., NEUPAUER R.M. Simulating unsteady flow, anabranching, and hyporheic dynamics in a glacial meltwater stream using a coupled surface water routing and groundwater flow model, Water Resour. Res. 47 (5), 2011.

7. MAKASKE B. Anastomosing pattern. Encyclopedia of Planetary Landforms, 1, 2014

8. PHILLIPS J.D. Logjams and avulsions in the San Antonio River delta. Earth Surface Processes and Landforms 37, 936, 2012.

9. LARKIN Z.T., TOOTH S., RALPH T.J., DULLER G.A.T., MCCARTHY T., KEEN-ZEBERT A., Humphries M.S. Timescales, mechanisms, and controls of incisional avulsions in floodplain wetlands: Insights from the Tshwane River, semiarid South Africa, Geomorphology 283, 158, 2017.

10. HEYVAERT, V. M. A., WALSTRA, J. The role of longterm human impact on avulsion and fan development. Earth Surf. Process. Landforms 41, 2137, 2016.

11. EDMONDS D.A., HAJEK E.A., DOWNTON N., BRYK A.B. Avulsion flow-path selection on rivers in foreland basins. Geology 44 (9), 695, 2016.

12. GRADZIŃSKI R., BARYŁA J., DOKTOR M., GMUR D., GRADZIŃSKI M., KĘDZIOR A., PASZKOWSKI M., SOJA R., ZIELIŃSKI T., ŻUREK S. Vegetation-controlled modern anastomosing system of the upper Narew River (NE Poland) and its sediments. Sedimentary Geology 157 (3), 253, 2003.

13. LEWIN J. Medieval environmental impacts and feedbacks: The lowland floodplains of England and Wales. Geoarchaeology-an Int. J. 25, 267, 2010.

14. SZMAŃDA J.B., LUC M. Danube river multichannel pattern between Ćunovo and Gabćíkovo - spatial analysis based on river classification after Brice. Landform Analysis 13, 129, 2010.

15. MIODUSZEWSKI W., NAPIÓRKOWSKI J., OKRUSZKO T. Narew National Park Protection Plan. Białystok, Narwiański Park Narodowy. 2014 [In Polish].

16. MARCINKOWSKI P., GRABOWSKI R.C., OKRUSZKO T. Controls on anastomosis in lowland river systems: towards process-based solutions to habitat conservation. Science of the Total Environment 609, 1544, 2017.

17. SZPORAK-WASILEWSKA S., PINIEWSKI M., KUBRAK J., OKRUSZKO T. What we can learn from a wetland water balance? Narew National Park case study. Ecohydrology \& Hydrobiology 15, 136, 2015.

18. VAUGHAN I.P., DIAMOND M., GURNELL A.M., HALL K.A., JENKINS A., MILNER N.J., NAYLOR L.A., SEAR D.A., WOODWARD G., ORMEROD S.J. Integrating ecology with hydromorphology: a priority for river science and management. Aquatic Conservation: Marine and Freshwater Ecosystems 19, 113, 2009.

19. BOON P.J., HOLMES N.T.H., RAVEN P.J. Developing standard approaches for recording and assessing river hydromorphology: the role of the European Committee for Standardization (CEN). Aquatic Conserv: Mar. Freshw. Ecosyst. 20, 55, 2010. 
20. GURNELL A.M., RINALDI M., BELLETTI B., BIZZI S., BLAMAUER B., BRACA G., BUIJSE T., BUSSETTINI M., CAMENEN B., COMITI F., DEMARCHI L., GARCÍA DE JALÓN D., GONZÁLEZ DEL TÁNAGO M., GRABOWSKI R.C., GUNN I.D.M., HABERSACK H., HENDRIKS D., HENSHAW A.J., KLÖSCH M., LASTORIA B., LATAPIE A., MARCINKOWSKI P., MARTÍNEZ-FERNÁNDEZ V., MOSSELMAN E., MOUNTFORD J.O., NARDI L., OKRUSZKO T., O'HARE M.T., PALMA M., PERCOPO C., SURIAN N., VAN DE BUND W., WEISSTEINER C., ZILIANI L. A multi-scale hierarchical framework for developing understanding of river behaviour to support river management. Aquatic Sciences 78, 1, 2015.

21. TOCKNER K., STANFORD J.A. Riverine flood plains: present state and future trends. Environ. Conserv. 29, 308, 2002.

22. JOHNSON S.E., AMATANGELO K.K., TOWNSEND P.A. WALLER D.M. Large, connected floodplain forests prone to flooding best sustain plant diversity. Ecology 97 (11), 3019, 2016.

23. KINGSFORD R.T., BASSET A., JACKSON L. Wetlands: conservation's poor cousins. Aquatic Conserv: Mar. Freshw. Ecosyst. 26, 892, 2016.

24. NEWSON M.D. Geomorphological concepts and tools for sustainable river ecosystem management. Aquatic Conserv: Mar. Freshw. Ecosyst. 12, 365, 2002.

25. CHARLTON, R. Fundamentals of fluvial geomorphology [book review]. Progress in Physical Geography 32 (3), 347, 2008.

26. BANASZUK H., BANASZUK P., GRADZIŃSKI R., KAMOCKI A.K., MIODUSZEWSKI W., OKRUSZKO T., PRÓCHNICKI P., SZEWCZYK M. Nature of Podlasie: Narew National Park Białystok: Narwiański Park Narodowy, 2004 [In Polish].

27. GONZALEZ DEL TANAGO M., GURNELL A.M., BELLETTI B., GARCIA DE JALON D. Indicators of river system hydromorphological character and dynamics: understanding current conditions and guiding sustainable river management. Aquatic Sciences 78, 35, 2016.

28. WATER FRAME DIRECTIVE. Directive 2000/60/EC of the European Parliament and of the council of 23 October 2000 establishing a framework for community action in the field of water policy. Official Journal of the European Communities L. 327, 1, 2000.

29. DEGIRMENDZIC J., KOŻUCHOWSKI K., ŻMUDZKA E. Changes of air temperature and precipitation in Poland in the period 1951-2000 and their relationship to atmospheric circulation, Int. J. Climatol. 24, 291, 2004.

30. CZARNECKA M., NIDZGORSKA-LENCEWICZ J. Multiannual variability of seasonal precipitation in Poland, Water-Environment-Rural Areas 2, 45, 2012 [In Polish].
31. MORÓN S., EDMONDS D.A., AMOS K. The role of floodplain width and alluvial bar growth as a precursor for the formation of anabranching rivers, Geomorphology 278, 78, 2017.

32. MAKASKE B., LAVOOI E., DE HAAS T., KLEINHANS M.G., SMITH D.G. Upstream control of river anastomosis by sediment overloading, upper Columbia River, British Columbia, Canada. Sedimentology 64 (6), 1488, 2017.

33. PIETSCH T.J., NANSON G.C., Bankfull hydraulic geometry; the role of in-channel vegetation and downstream declining discharges in the anabranching and distributary channels of the Gwydir distributive fluvial system, southeastern Australia, Geomorphology 129 (1), 152, 2011.

34. NANSON G.C. Anabranching and anastomosing rivers. In E. Wohl (Eds.), Treatise on Geomorphology 9, 330, 2013.

35. CARLING P., JANSEN J., MESHKOVA L. Multichannel rivers: their definition and classification. Earth Surf. Process. Landforms 39 (1), 26, 2014.

36. GARCIA RUIZ J.M., LANA-RENAULT N. Hydrological and erosive consequences of farmland abandonment in Europe, with special reference to the Mediterranean region. A review. Agric. Ecosyst. Environ. 140, 317, 2011.

37. GRABOWSKI R.C., GURNELL A.M. Diagnosing problems of fine sediment delivery and transfer in lowland, Nothwest European catchments: the Frome catchment, southern England. Aquatic Sciences 78, 95, 2015.

38. MESHKOVA L.V., CARLING P.A. Discrimination of alluvial and mixed bedrock-alluvial multichannel river networks. Earth Surf. Process. Landforms, 38, 1299, 2013

39. LEWANDOWSKI P. Polish Investigations on River Hydromorphology. Pol. J. Environ. Stud. 21 (4), 957, 2012.

40. NANSON G.C., HUANG H.Q. Self-adjustment in rivers: Evidence for least action as the primary control of alluvialchannel form and process. Earth Surf. Process. Landforms 42, 575, 2016.

41. SAYNOR M.J., ERSKINE W.D. Classification of River Reaches on the Little Disturbed East Alligator River, Northern Australia. International Journal of Geosciences 4, 53, 2013.

42. ŻELAZO J., POPEK Z. Elementary restoration. SGGW, Warszawa. 2002 [In Polish].

43. GEBLER D., SZOSZKIEWICZ K., BIELAK S.R. Diversity of hydromorphological conditions of rivers in the lowland and mountain catchment scale. Nauka Przyr. Technol. 7 (4), $50,2013$.

44. NASIŁOWSKA S. Land use change in the Upper Narew Catchment in XIX-XX century. Teledetekcja Środowiska 40, 2008 [In Polish]. 